\title{
Connectivity in reef fish assemblages between seagrass and coral reef habitats
}

\author{
Stuart J. Campbell*, Tasrif Kartawijaya, Etwin K. Sabarini \\ Marine Programs, Wildlife Conservation Society, Jalan Burangrang 18, Bogor, West Java 16151, Indonesia
}

\begin{abstract}
Coral reefs and seagrass beds form extensive shallow-water habitats, but few reports have assessed the extent to which fishes on coral reefs are segregated from or integrated with fish from seagrass habitats. To investigate this, we used visual census surveys to survey reef fish assemblages in 3 habitat types: (1) seagrass, (2) transition areas between seagrass and coral reef and (3) coral reefs, at 8 locations in an Indonesian marine protected area. Based on the density of juveniles and adults, 66 of the 212 fish species recorded were classified into 4 ecological groups: seagrass residents, generalists, nursery species and coral residents. Coral residents and nursery species were found in reef and transition habitats, seagrass residents in seagrass beds and transition habitats, and generalists showed a gradual decrease in density from coral reef to seagrass beds. In terms of reef fish density, seagrass residents and nursery species accounted for 21 and $17 \%$, respectively, of the 66 species classified into ecological groups. Habitat segregation among life stages of some nursery species, where adults were found in a coral habitat and juveniles in seagrass, was indicative of ontogenetic shifts from seagrass to coral habitat. Segregation in the distribution of feeding groups among habitat types also occurred, with nocturnal piscivores and diurnal zoobenthivores mostly found in coral and transition habitats, while nocturnal zoobenthivores, herbivores and diurnal piscivores were mostly found in seagrass and transition habitats. These patterns differ from those reported in similar habitat types elsewhere, but overall the results support previous findings, i.e. that optimisation of predatory and resource competition mechanisms may be responsible for habitat segregation of fish species, life stages and feeding groups.
\end{abstract}

KEY WORDS: Seagrass · Coral reefs · Habitat linkages $\cdot$ Reef fish $\cdot$ Trophic groups $\cdot$ Indonesia

\section{INTRODUCTION}

Seagrass habitats provide refuge for fish species from predation. An enhanced production of food occurs, either directly, through increased production of epifauna on seagrass leaves, or indirectly, through the generation of detritus (Jenkins et al. 1997). These habitats also support coral reef productivity principally due to their role as feeding habitat for predatory fish (Unsworth et al. 2008). Increasingly, information on the linkages between fish communities in coastal habitats (Nagelkerken et al. 2000a, Mumby et al. 2004, Nakamura \& Sano 2004a, Dorenbosch et al. 2005, 2007, Nemeth 2009) and the role of seagrass as nursery, feeding and resting habitat for coral reef fishes (Nagelkerken et al. 2000b, 2001, Horinouchi et al. 2005,
Mumby 2006, Nagelkerken 2009) is essential to understand the connectivity of marine habitats for conservation management purposes (Sale et al. 2005).

Despite strong evidence that seagrass habitats provide functional roles and support ecological processes for reef fishes, biodiversity and conservation measures often focus solely on coral reefs and give little or no consideration to seagrass habitats as fish habitats (Unsworth \& Cullen 2010). In many tropical regions, seagrass habitats provide areas for important subsistence fisheries (Gell \& Whittington 2002, Stoner 2003, Ashworth et al. 2004, de la Torre-Castro \& Rönnbäck 2004, Unsworth \& Cullen 2010), while fishing intensity and the removal of top-down predatory fish species may also shape the community structure of seagrass habitats (Eklöf et al. 2009). Removal of herbivorous 
fishes and economically important fish in seagrasses can also reduce herbivory (Lugendo et al. 2006), leading to increased epiphytic overgrowth and lowering of seagrass resilience. Overexploitation of fishes could therefore be a major driver of seagrass loss (Heck \& Valentine 2007, Moksnes et al. 2008, Eklöf et al. 2009), alter the trophic structure of reef fishes in seagrasses and lower the resilience and recovery of coral reefs from impacts such as coral bleaching (Mumby et al. 2006).

Relatively little knowledge exists on these ecological interactions and seagrass dynamics in South East Asia (Kirkman \& Kirkman 2002, Spalding et al. 2003, Waycott et al. 2009). Studies in the Caribbean have shown that lagoons and bays containing mangroves and seagrass beds harbour high densities of juveniles of at least 17 different reef fish species (Nagelkerken et al. 2000 b, 2001, 2002). Both mangroves and seagrasses have been found to strongly influence the community structure of fish in neighbouring reefs, with habitat influencing segregation between species and life stages in the Caribbean (Nagelkerken et. al. 2000b, 2001, 2002, Mumby et al. 2004) and East Africa (Dorenbosch et al. 2004, 2007). Most of these studies were from subtidal areas where connectivity among habitats is permanent. The limited number of studies conducted in South East Asia are from intertidal habitats, where seagrasses commonly lie adjacent to coral reefs on fringing reefs and lagoons, offering temporary habitat and therefore potentially different functions for reef fishes (Sheaves 2005, Unsworth et al. 2008, 2009a,b).

The interactions of fish species between seagrasses and corals have been defined as a functional process where fish communities between habitats directly or indirectly influence each other by migratory, competitive and predatory mechanisms (Dorenbosch et al. 2005). In most cases, studies on the interlinkages between reef fish communities in seagrass and coral reefs have examined ontogenetic and feeding migration from these habitat types when located hundreds of metres apart (Nagelkerken et. al. 2001, Nakamura \& Sano 2004a, Mumby 2006), and few studies have examined these migrations at the species level (Mumby 2006, Unsworth et al. 2009a,b). To date, only 1 study has examined fine-scale migration distances $(<60 \mathrm{~m})$ of fishes along a seagrass-coral reef gradient (Dorenbosch et al. 2005), where coral habitats had higher fish densities and diversity compared with transition and seagrass habitats, and changes in the densities of ecological groups were found along these gradients. The pattern was equated with the 'edge' effect in terrestrial ecology, where species show increases, decreases or no change in density in relation to habitat changes (Ries \& Sisk 2004). Such effects can result in habitat segregation and structuring of fish communities which are modified by competitive and predatory interactions among species, ecological groups and life stages at the habitat interface (Nagelkerken \& van der Velde 2004, Dorenbosch et al. 2007).

One method of assessing the interactions of fish species along seagrass-coral reef gradients is by simultaneous comparison of fish communities and ecological groups in both habitats (Jenkins et al. 1997, Nakamura \& Sano 2004a, Dorenbosch et al. 2005, 2007). In South East Asia, and in particular Indonesia, we have some information on such patterns (Unsworth et al. 2008, $2009 a, b)$, yet studies examining the relative changes in the density of taxonomic or ecological groupings of species along habitat gradients are few, and our knowledge of which fishes are important seagrass nursery species is especially limited. This is important, as management actions such as the placement of protected areas and development of fisheries regulations may require knowledge of the resource requirements of different commercial species and species of high ecological importance.

To 'field test' present-day theories of the influence of the connectivity between seagrass and coral reef habitats on the configuration of the fish assemblages, we examined fish species along seagrass-coral reef gradients in Karimunjawa Marine National Park in Indonesia with the aim of testing (1) whether fish composition in the seagrass beds, transition areas and coral reefs showed consistent patterns of change, in terms of ecological groups (Dorenbosch et al. 2005), along replicated habitat gradients, (2) whether particular life stages of fish had a specificity for seagrass beds that may therefore serve as important juvenile habitat for reef species and (3) whether densities of different ecological and feeding groups changed with habitat type. To test these hypotheses, we surveyed benthic features including corals, macroalgae and seagrass, and reef fish densities along 8 seagrass-coral reef gradients of varying distances that broadly represented typical configurations of these habitats in Karimunjawa.

\section{MATERIALS AND METHODS}

Study area. Karimunjawa National Park (KNP) includes a group of islands located $\sim 70 \mathrm{~km}$ north of Java, Indonesia (Fig. 1) and contains 1047 ha of seagrass and 7641 ha of coral reef habitats. The present study was conducted from 10 to 18 September 2005. The coastal zone is characterised by high coverage of seagrass and coral reefs, with some coastal areas dominated by mangroves. Where they occur, mangroves are adjacent and less than $10 \mathrm{~m}$ from the landward edge of seagrass beds and are exposed at low tide. Dominant species include Ceriops tagal, Brugruiera cylindrica, $B$. gymnorriza, B. sexangula, Excoecaria agallocha, Lum- 


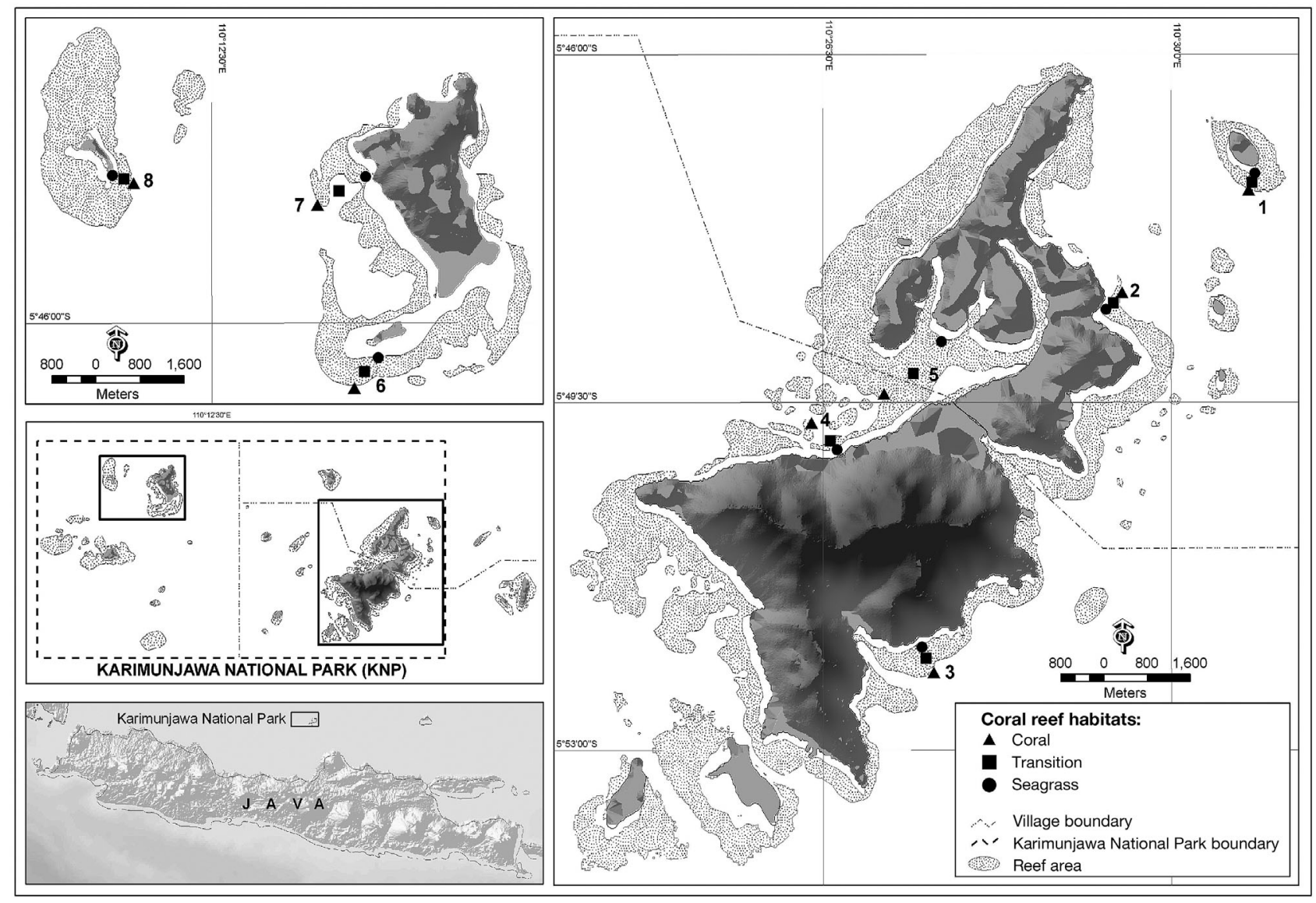

Fig. 1. Location of all sampling sites in the seagrass, transition and coral reef habitats in Karimunjawa National Park. Symbols refer to sites (habitats; $n=24)$ and numbers refer to locations of sites $(n=8)$ in Table 1

nitzera littorea, Rhizophora apiculata, R. mucronata, $R$. stylosa and Xylocarpus granatum. Seagrass beds consist of mixed seagrasses dominated by Enhalus acoroides and/or Thalassia hemprichii, and Cymodocea serrulata and/or Halophila ovalis. Transition habitats were mostly sandy seabeds with occasional patches of $H$. ovalis and T. hemprichii and patchy hard corals that were located between the seagrass and coral reefs. Coral sites were characterised by generally complex and species-rich communities of hard corals at the edge of fringing reefs on reef crests $(2-4 \mathrm{~m})$ and reef slopes $(6-8 \mathrm{~m})$.

Eight marine locations, with no riverine influence, were chosen adjacent to islands where a seagrasscoral reef gradient existed (Fig. 1). All locations were well away from the immediate vicinity of large population centres and were not considered to be affected by land-based anthropogenic factors. To study the density of different fish assemblages along the seagrass-coral reef gradient, 3 habitats were distinguished: seagrass (at least $50 \mathrm{~m}$ into the seagrass beds and away from outer edges), transition (inside sandy, patchy seagrass and coral areas away from edges of continuous sea- grass and coral habitats) and coral (reef crests and reef slopes located on the outer seaward edge of the reef in continuous coral cover). Seagrass habitats were intertidal, ranging from 0.53 to $0.71 \mathrm{~m}$ tidal height at the time of sampling. Salinity and temperature $\left({ }^{\circ} \mathrm{C}\right) \operatorname{did}$ not vary among the 8 locations and 24 sites (Table 1). Current speed also ranged from weak to strong among sites, and fishing pressure from artisanal fishing boats across the 8 locations was relatively low and ranged from 0.05 to 0.18 fishing trips $\mathrm{d}^{-1}$ (Campbell \& Pardede 2006). Mangroves occurred in proximity to 5 of the 8 locations in KNP (Table 1).

At each of the 8 locations, 3 replicate visual transects were sampled within seagrass and transition habitats, and 6 replicate visual transects were sampled within coral habitat, yielding a total of 96 transects at 24 sites (Fig. 1). Transects at the seagrass and transition sites were laid at least $50 \mathrm{~m}$ into their respective habitats parallel to the shore. Transects at coral sites were laid in continuous coral cover on reef crests $(2-4 \mathrm{~m})$ and reef slopes $(6-8 \mathrm{~m})$ parallel to shore. The distance from seagrass to transition to coral reef differed among locations, and ranged from 270 to $1450 \mathrm{~m}$. The distance to 
Table 1. Depth, distance to shore, visibility, tidal difference and current speed at 24 sites at 8 locations (see Fig. 1), and the presence/absence of mangroves in proximity to all survey sites. Salinity was 33 and temperature was $30^{\circ} \mathrm{C}$ at all sites

\begin{tabular}{|c|c|c|c|c|c|c|c|}
\hline $\begin{array}{l}\text { Habitat/ } \\
\text { location }\end{array}$ & $\begin{array}{c}\text { Loc. } \\
\text { no. }\end{array}$ & $\begin{array}{c}\text { Dist. to } \\
\text { shore }(\mathrm{m})\end{array}$ & $\begin{array}{l}\text { Depth } \\
\text { (m) }\end{array}$ & $\begin{array}{l}\text { Visibility } \\
(\mathrm{m})\end{array}$ & $\begin{array}{c}\text { Tidal } \\
\text { height }(\mathrm{m})\end{array}$ & Currents & Mangrove \\
\hline \multicolumn{8}{|l|}{ Seagrass } \\
\hline Batuputih & 2 & 38 & 0.5 & 1 & 0.56 & Weak & Present \\
\hline Kembar & 8 & 39 & 0.6 & 4 & 0.71 & Medium & Present \\
\hline Kumbang & 6 & 80 & 0.5 & 3 & 0.67 & Medium & Absent \\
\hline Legon Janten & 3 & 70 & 0.5 & 4 & 0.53 & Medium & Absent \\
\hline Parang & 7 & 139 & 0.5 & 2 & 0.67 & Weak & Present \\
\hline Sintok & 1 & 72 & 0.3 & 5 & 0.56 & Strong & Absent \\
\hline Tanjung Gelam & 4 & 95 & 0.5 & 1 & 0.71 & Weak & Present \\
\hline Terusan & 5 & 68 & 0.4 & 1 & 0.55 & Weak & Present \\
\hline \multicolumn{8}{|l|}{ Transition area } \\
\hline Batuputih & 2 & 278 & 1.5 & 2 & Subtidal & Weak & Present \\
\hline Kembar & 8 & 189 & 1.0 & 4 & Subtidal & Medium & Present \\
\hline Kumbang & 6 & 352 & 0.8 & 4 & Subtidal & Medium & Absent \\
\hline Legon Janten & 3 & 265 & 1.5 & 5 & Subtidal & Medium & Absent \\
\hline Parang & 7 & 420 & 1.0 & 3 & Subtidal & Weak & Present \\
\hline Sintok & 1 & 149 & 1.5 & 5 & Subtidal & Strong & Absent \\
\hline Tanjung Gelam & 4 & 427 & 1.0 & 2 & Subtidal & Weak & Present \\
\hline Terusan & 5 & 1304 & 2.0 & 2 & Subtidal & Weak & Present \\
\hline \multicolumn{8}{|l|}{ Coral } \\
\hline Batuputih & 2 & 513 & 3.5 & 4 & Subtidal & Weak & Present \\
\hline Kembar & 8 & 338 & 3.5 & 6 & Subtidal & Medium & Present \\
\hline Kumbang & 6 & 1931 & 4.0 & 5 & Subtidal & Medium & Absent \\
\hline Legon Janten & 3 & 1856 & 4.0 & 7 & Subtidal & Medium & Absent \\
\hline Parang & 7 & 627 & 4.0 & 5 & Subtidal & Weak & Present \\
\hline Sintok & 1 & 285 & 4.0 & 6 & Subtidal & Strong & Absent \\
\hline Tanjung Gelam & 4 & 1817 & 4.0 & 4 & Subtidal & Weak & Present \\
\hline Terusan & 5 & 1563 & 4.0 & 4 & Subtidal & Weak & Present \\
\hline
\end{tabular}

shore of coral sites ranged from 285 to $1931 \mathrm{~m}$, while seagrass sites were located 38 to $139 \mathrm{~m}$ from shore (Table 1).

Habitats were sampled using an underwater visual census method with SCUBA and $50 \mathrm{~m}$ belt transects. For seagrass and macroalgae, visual estimates of percent cover were made within $50 \times 50 \mathrm{~cm}$ quadrats placed every $5 \mathrm{~m}$ along each transect (see Campbell \& McKenzie 2004). Hard coral cover estimates were sampled using a point intercept method where presence and absence of live hard coral was recorded at each $0.5 \mathrm{~m}$ along the $50 \mathrm{~m}$ belt transects. Fish species in each habitat were also sampled with SCUBA using visual census methods along each belt transect (Campbell \& Pardede 2006). All fish (excluding the families Gobiidae, Blenniidae and Tripterygiidae) were recorded to species level. In order to conduct the visual transects, observers were trained at estimating fish lengths underwater by repeatedly estimating the lengths of objects of known length underwater (English et al. 1997). Surveys were carried out as close to high tide as possible and between 10:00 and 14:00 h, to avoid possible effects of daily tidal migrations (Unsworth et al. 2007a). Fish species, size and frequency were recorded within $5 \mathrm{~cm}$ intervals from 0 to $>40 \mathrm{~cm}$. For some trophic groups (e.g. omnivores), the above described methods may underestimate numbers of fish compared with nighttime abundance (Unsworth et al. 2007b), but, in the present study, provided comparable estimates among different habitats during daytime. Fishes less than $10 \mathrm{~cm}$ in length were recorded along $50 \times 2 \mathrm{~m}$ belt transects giving a total area of $100 \mathrm{~m}^{2}$. Fishes greater than $10 \mathrm{~cm}$ were recorded along $50 \times 5 \mathrm{~m}$ belt transects giving a total sampling area of $250 \mathrm{~m}^{2}$. In order to compare data between habitats and with other studies, all density data are presented as total number of fish (individuals) $\mathrm{ha}^{-1}$.

We used the approach of classifying juvenile and adult fish species according to ecological groupings defined a priori (Dorenbosch et al. 2005). Fish were recorded as juveniles when they were smaller than 1/3 of the maximum species length, obtained from Froese \& Pauly (2006). Based on the density distribution of juveniles and adults of each fish species along seagrass-coral reef gradiant, the 66 species were then classified into 1 of 4 ecological groups: coral residents, generalists, nursery species and seagrass residents (Dorenbosch et al. 2005). All 66 species were also classified into feeding groups according to Froese \& Pauly (2006). 
Data analysis. Mean percentage cover of seagrass and macroalgae at each site $(n=24)$ was derived from mean values of replicate quadrats $(n=10)$ of each belt transect $(n=3)$. Mean percent hard coral cover at each site was calculated from the mean percentage of points of each replicate transect $(n=6)$ that contained live hard coral. Mean numbers of fish species and fish densities at each site were derived from mean values of replicate belt transects ( $\mathrm{n}=3$ in seagrass and transition, $\mathrm{n}=6$ in coral) at each site and used in all subsequent analyses.

A principal component analysis (PCA) used a covariance matrix, and was performed on the distribution of $\log _{10}(x+1)$ transformed juvenile and adult densities of the 66 fish species assigned to ecological groups in each of the 3 habitats, in order to assess the suitability of the ecological classifications of Dorenbosch et al. (2005) for this suite of species. To examine whether seagrass characteristics influenced fish density, we used linear regression to examine the relationship between mean total, adult and juvenile fish densities with seagrass cover (\%) and seagrass canopy height $(\mathrm{cm})$ at each seagrass habitat, at each location $(\mathrm{n}=8)$. and omnivores, detritivores, planktivores), data were not included in the analysis. We used separate 2-way ANOVAs to test for effects of habitat (fixed; 3 levels, as above) and diurnal feeding groups (fixed; 4 levels: zoobenthivores, piscivores, herbivores, omnivores), and habitat and nocturnal feeding groups (fixed; 2 levels: zoobenthivores, piscivores) on fish densities (ecological groups and life stage pooled).

All data were tested for normality and if not normal, were $\log _{10}(x+1)$ transformed before analysis. Tukey post hoc comparisons were used to examine significant differences $(\mathrm{p}<0.05)$ among all means.

\section{RESULTS}

\section{Marine benthic communities}

At 7 seagrass sites, the composition and percent cover of seagrass species consisted primarily of Enhalus acoroides and/or Thalassia hemprichii, and depending on the site examined, was mixed with Cymodocea serrulata and/or Halophila ovalis. At the 1 site with lowest sea-
Using 2-way analysis of covariance (ANCOVA) we tested for effects of habitat (fixed; 3 levels: coral, transition, seagrass), and ecological group (fixed, 4 levels: coral residents, generalists, nursery species, seagrass residents) on mean fish densities (adults and juveniles pooled). The distance from shore may also influence movement and behaviour of reef fish and may therefore influence fish densities among habitats, so the effect of distance to shore of each of the 24 survey sites was tested as a covariate. We additionally used 1-way ANCOVA to test for effects of habitat (fixed; 3 levels: coral, transition, seagrass) on each of the 4 ecological groups, using distance to shore as the covariate to identify any effect it may have on individual ecological groups.

Mean densities of fish may also vary according to their life history, so we used 2-way ANOVA to test for effects of habitat (fixed; 3 levels, as above) and life stage (fixed; 2 levels, juvenile, adult) on fish densities of each ecological group separately.

Feeding ecology may also influence reef fish density among habitats (Dorenbosch et al. 2005). Where there were $<2$ samples recorded for a given feeding guild (i.e. nocturnal herbivores
Table 2. Depth, \% cover, dominant seagrass species and canopy height in seagrass, transition and coral reef habitats (see Fig. 1) in Karimunjawa National Park. EA: Enhalus acoroides; TH: Thalassia hemprichii; CS: Cymodocea serrulata; CR: C. rotundata; HO: Halophila ovalis. -: no seagrass found

\begin{tabular}{|c|c|c|c|c|c|c|}
\hline Habitat/location & $\begin{array}{l}\text { Loc. } \\
\text { no. }\end{array}$ & $\begin{array}{l}-\% \\
\text { Seagrass }\end{array}$ & $\begin{array}{l}\text { o cover } \\
\text { Algae }\end{array}$ & Coral & $\begin{array}{l}\text { Dominant } \\
\text { species }\end{array}$ & $\begin{array}{c}\text { Canopy } \\
\text { height }(\mathrm{cm})\end{array}$ \\
\hline \multicolumn{7}{|l|}{ Seagrass } \\
\hline Batuputih & 2 & 70.0 & 3.0 & 0.0 & EA/TH & 40 \\
\hline Kembar & 8 & 41.7 & 5.0 & 0.0 & TH/CS & 16 \\
\hline Kumbang & 6 & 20.0 & 12.0 & 0.0 & TH/HO & 15 \\
\hline Legon Janten & 3 & 9.3 & 3.0 & 0.0 & $\mathrm{HO} / \mathrm{CR}$ & 12 \\
\hline Parang & 7 & 65.0 & 10.0 & 0.0 & EA/TH & 36 \\
\hline Sintok & 1 & 42.3 & 1.0 & 0.0 & TH & 15 \\
\hline Tanjung Gelam & 4 & 16.7 & 40.0 & 0.0 & EA/CS & 38 \\
\hline Terusan & 5 & & 5.0 & 0.0 & EA & 38 \\
\hline \multicolumn{7}{|l|}{ Transition area } \\
\hline Batuputih & 2 & 5.6 & 0.0 & 8.0 & $\mathrm{HO} / \mathrm{TH}$ & \\
\hline Kembar & 8 & 0.0 & 0.0 & 1.9 & - & \\
\hline Kumbang & 6 & 0.9 & 0.0 & 25.5 & $\mathrm{HO}$ & \\
\hline Legon Janten & 3 & 9.1 & 0.0 & 14.8 & $\mathrm{HO}$ & \\
\hline Parang & 7 & 0.0 & 0.0 & 9.5 & - & \\
\hline Sintok & 1 & 0.0 & 0.0 & 8.3 & - & \\
\hline Tanjung Gelam & 4 & 0.0 & 0.0 & 18.2 & - & \\
\hline Terusan & 5 & 9.2 & 0.0 & 10.9 & TH & \\
\hline \multicolumn{7}{|l|}{ Coral } \\
\hline Batuputih & 2 & 0.0 & 52.3 & 37.5 & - & \\
\hline Kembar & 8 & 0.0 & 54.2 & 37.0 & - & \\
\hline Kumbang & 6 & 0.0 & 44.9 & 48.5 & - & \\
\hline Legon Janten & 3 & 0.0 & 49.5 & 62.0 & - & \\
\hline Parang & 7 & 0.0 & 43.2 & 38.5 & - & \\
\hline Sintok & 1 & 0.0 & 42.9 & 48.5 & - & \\
\hline Tanjung Gelam & 4 & 0.0 & 35.6 & 55.7 & - & \\
\hline Terusan & 5 & 0.0 & 43.3 & 59.5 & - & \\
\hline
\end{tabular}


grass cover, both $H$. ovalis and $C$. rotundata were the dominant species. Seagrass canopy height ranged from 12 to $40 \mathrm{~cm}$ and seagrass cover ranged from 9.3 to $70.0 \%$ (Table 2). Algal cover varied across the 8 seagrass sites from 3.0 to $40.0 \%$, and no coral was found at these sites. The transition sites located between the seagrass and coral reefs were characterised by sand, and some sites had a low cover (0.0 to $9.2 \%)$ of $H$. ovalis and T. hemprichii and patchy (1.9 to $25.5 \%$ ) hard coral. Sites located on coral reefs were characterised by generally complex and species-rich communities of hard corals (37.0 to $62.0 \%$ ) at the edge of fringing reefs on reef crests (2-4 m) and reef slopes (6-8 m; Table 2). Seagrasses were absent at the coral reef sites (Table 2).

\section{Fish community}

In total, 212 fish species from 34 families were recorded in the seagrass (50 species), transition (89) and coral reef (180) sites. The mean $( \pm$ SE) number of fish species in the entire fish assemblage was significantly
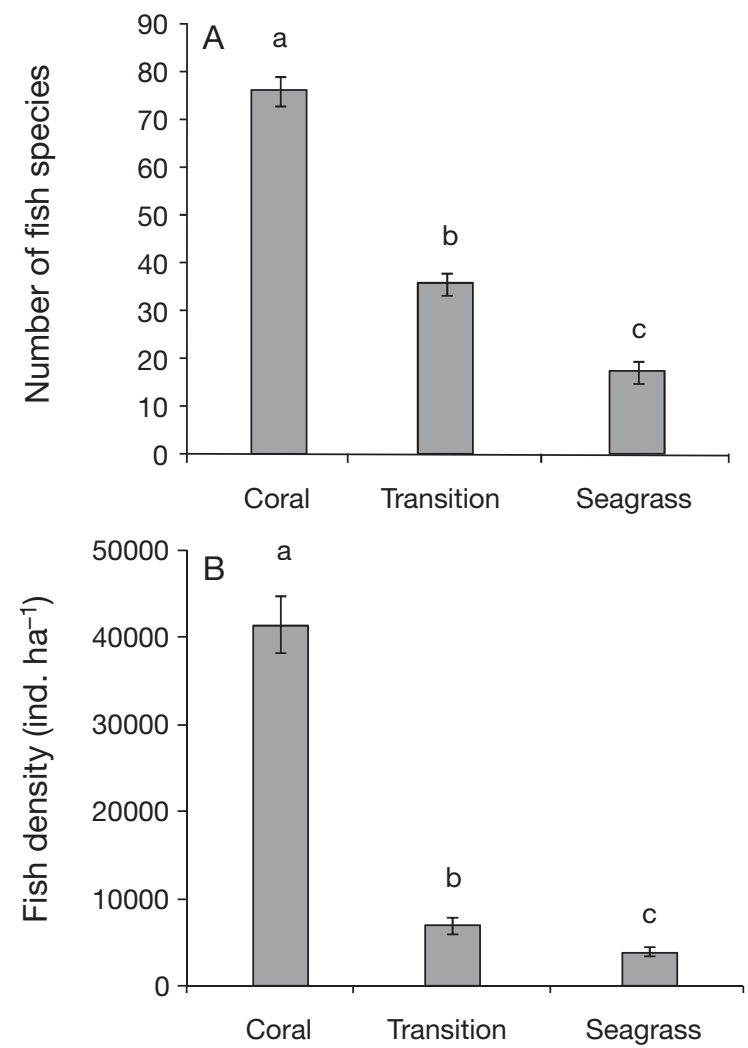

Fig. 2. Mean ( $\pm \mathrm{SE}, \mathrm{n}=8)$ number of species (A) and total density of the entire fish assemblage (all species pooled) (B) in different habitats (seagrass, transition and coral reef) in Karimunjawa National Park. Comparisons of mean values among habitat types were made using 1-way ANOVA. Significant $(\mathrm{p}<0.05)$ Tukey pairwise differences in mean values among habitat types are denoted by different letters higher $\left(F_{2,21}=146.10, \mathrm{p}<0.001\right)$ at coral sites $(76.0 \pm$ $3.1)$ than at transition sites $(35.6 \pm 2.2)$, which in turn was significantly higher than at seagrass sites (17.2 \pm 2.1; Fig. 2). Mean ( \pm SE) fish density was also significantly higher $\left(F_{2,21}=104.25, \mathrm{p}<0.001\right)$ at coral (41448 \pm 3318) than transition sites (6898 \pm 929.4), which was higher than the mean density of fish at seagrass sites (3876 \pm 592; Fig. 2).

A total of 66 fish species could be grouped into feeding guilds according to Froese \& Pauly (2006) and into 1 of 4 ecological groups (coral residents, generalists, nursery species, seagrass residents) based on measurements of size and frequency among the 3 habitat types (Table 3). Generalists were represented by the greatest number of species (20) compared with seagrass residents (17), coral residents (15) and nursery species (14) (Table 3). Coral residents, generalists, nursery species and seagrass residents comprised 43.3, $18.5,17.0$ and $21.2 \%$, respectively, of the overall fish density of the 66 fish species (Table 3 ).

PCA of the 66 juvenile and adult fish species in the 3 habitat types showed that clusters of juvenile and adult species corresponded with the classification of the species into the 4 ecological groups (Fig. 3).

Among the 8 seagrass sites, there was no significant relationship between seagrass cover (\%) and total fish density $\left(F_{1,7}=0.001, \mathrm{p}>0.05\right)$, adult fish density $\left(F_{1,7}=\right.$ $4.48, \mathrm{p}>0.05)$ or juvenile fish density $\left(F_{1,7}=1.99, \mathrm{p}>\right.$ 0.05). Similarly, seagrass canopy height $(\mathrm{cm})$ was not related to total fish density $\left(F_{1,7}=0.85, \mathrm{p}>0.05\right)$, adult fish density $\left(F_{1,7}=1.15\right.$, p $\left.>0.05\right)$ or juvenile fish density $\left(F_{1,7}=2.98, \mathrm{p}>0.05\right)$.

Using 2-way ANCOVA, a significant interaction between habitat and ecological group $\left(F_{6,83}=18.02\right.$, $\mathrm{p}<0.001$ ) was explained by higher mean densities of coral residents in corals compared with transition habitat and higher densities of generalists and nursery species in corals than in transition and seagrass habitats, while no effect of habitat was found on the mean densities of seagrass residents (Fig. 4). No overall effect of distance to shore on mean fish densities was found $\left(F_{1,83}=3.25, \mathrm{p}=0.075\right)$, but when densities of fish in each ecological group were tested separately using 1-way ANCOVA, we found that densities of coral residents were positively related to distance from shore $\left(F_{1,20}=74.16, \mathrm{p}=0.022\right)$, and seagrass resident densities were negatively related to distance from shore $\left(F_{2,20}=5.95, \mathrm{p}=0.024 ;\right.$ Fig. 4$)$. No effect of distance to shore on generalists $\left(F_{1,20}=0.39, \mathrm{p}>0.05\right)$ or nursery species $\left(F_{1,20}=0.54, \mathrm{p}>0.05\right)$ was found.

Using 2-way ANOVA to test for effects of habitat and life history on mean fish densities for each ecological group, we found a significant effect of habitat $\left(F_{2,42}=\right.$ 94.07, $\mathrm{p}<0.001$ ) on coral residents. Post hoc tests revealed higher densities of juveniles and adults in 
Table 3. Mean fish densities per species and total number of species per ecological group (all sites pooled) for each of the 3 habitat zones. Feeding activity defined as d: diurnal, n: nocturnal. Feeding guilds (based on Froese \& Pauly 2006) were distinguished as O: omnivore, P: planktivore, C: piscivore, H: herbivore, Z: zoobenthivore, D: detritivore

\begin{tabular}{|c|c|c|c|c|c|c|}
\hline \multirow[t]{2}{*}{ Species } & \multirow[t]{2}{*}{ Feeding activity } & \multirow[t]{2}{*}{ Feeding guild } & \multicolumn{4}{|c|}{ Density (ind. ha ${ }^{-1}$ ) } \\
\hline & & & Coral & Transition & Seagrass & Total \\
\hline \multicolumn{7}{|l|}{ Coral residents } \\
\hline Abudefduf sexfasciatus & $\mathrm{d}$ & $\mathrm{O}$ & 1266.7 & 136.7 & & 1403.4 \\
\hline Balistapus undulatus & $\mathrm{d}$ & $\mathrm{O}$ & 55.0 & & & 55.0 \\
\hline Caesio cunning & $\mathrm{d}$ & $\mathrm{P}$ & 1820.0 & & & 1820.0 \\
\hline Cephalopholis microprion & $\mathrm{n}$ & $\mathrm{C}$ & 88.8 & & & 88.8 \\
\hline Cetoscarus bicolor & $\mathrm{d}$ & $\mathrm{H}$ & 90.0 & & & 90.0 \\
\hline Chlorurus microrhinus & $\mathrm{d}$ & $\mathrm{H}$ & 77.5 & & & 77.5 \\
\hline Chromis atripectoralis & $\mathrm{d}$ & $\mathrm{O}$ & 5394.7 & 130.0 & & 5524.7 \\
\hline Coris batuensis & $\mathrm{d}$ & BI & 232.5 & 20.0 & & 252.5 \\
\hline Dascyllus reticulatus & $\mathrm{d}$ & $\mathrm{O}$ & 250.0 & & & 250.0 \\
\hline Diproctacanthus xanthurus & $\mathrm{d}$ & BI & 281.3 & 73.3 & & 354.6 \\
\hline Halichoeres hortulanus & $\mathrm{d}$ & BI & 76.7 & 20.0 & & 96.7 \\
\hline H. marginatus & $\mathrm{d}$ & BI & 142.5 & & & 142.5 \\
\hline H. melanochir & $\mathrm{d}$ & BI & 201.9 & 40.0 & & 241.9 \\
\hline Oxycheilinus diagrammus & $\mathrm{d}$ & BI & 59.2 & & & 59.2 \\
\hline Thalassoma lunare & $\mathrm{d}$ & BI & 456.6 & 85.0 & & 541.6 \\
\hline Total no. of coral residents & & & 15 & 7 & $\mathbf{0}$ & 22.0 \\
\hline Total coral resident density (in & $\left.a^{-1}\right)$ & & 10036.8 & 420.0 & 0.0 & 10456.8 \\
\hline Coral resident density $(\%)$ & & & 96.0 & 4.0 & 0.0 & 100 \\
\hline \multicolumn{7}{|l|}{ Generalists } \\
\hline Abudefduf vaigiensis & $\mathrm{d}$ & $\mathrm{O}$ & 66.7 & 140.0 & 60.0 & 266.7 \\
\hline Apogon cyanosoma & $\mathrm{n}$ & $\mathrm{P}$ & 1000.0 & 300.0 & 80.0 & 1380.0 \\
\hline Cheilinus fasciatus & $\mathrm{d}$ & BI & 127.4 & 30.0 & & 157.4 \\
\hline C. trilobatus & $\mathrm{d}$ & BI & 73.3 & 20.0 & & 93.3 \\
\hline Chlorurus sordidus & $\mathrm{d}$ & $\mathrm{H}$ & 105.6 & 595.0 & 20.0 & 720.6 \\
\hline Dischistodus chrysopoecilus & $\mathrm{d}$ & $\mathrm{O}$ & 100.0 & 113.3 & 92.0 & 305.3 \\
\hline Epibulus insidiator & $\mathrm{d}$ & BI & 182.1 & 20.0 & 20.0 & 222.1 \\
\hline Epinephelus merra & $\mathrm{n}$ & $\mathrm{C}$ & 24.0 & 50.0 & & 74.0 \\
\hline Halichoeres chloropterus & $\mathrm{d}$ & BI & 183.3 & 195.0 & 203.3 & 581.6 \\
\hline H. scapularis & $\mathrm{d}$ & BI & 100.0 & 191.9 & 73.3 & 365.2 \\
\hline Lethrinus erythropterus & $\mathrm{d}$ & $\mathrm{C}$ & 80.0 & 100.0 & & 180.0 \\
\hline Lutjanus decussatus & $\mathrm{n}$ & $\mathrm{C}$ & 36.7 & 82.5 & 20.0 & 139.2 \\
\hline Neoglyphidodon melas & $\mathrm{d}$ & $\mathrm{O}$ & 284.9 & 129.2 & & 414.1 \\
\hline Oxycheilinus celebicus & $\mathrm{d}$ & BI & 75.0 & 60.0 & & 135.0 \\
\hline Pomacentrus amboinensis & $\mathrm{d}$ & $\mathrm{O}$ & 131.3 & 170.0 & & 301.3 \\
\hline P. chrysurus & $\mathrm{d}$ & $\mathrm{O}$ & 484.4 & 199.2 & 66.7 & 750.3 \\
\hline Scarus ghobban & $\mathrm{d}$ & $\mathrm{H}$ & 60.0 & 45.0 & & 105.0 \\
\hline Scolopsis margaritifer & $\mathrm{d}$ & BI & 55.9 & 66.1 & & 122.0 \\
\hline Siganus virgatus & $\mathrm{d}$ & $\mathrm{H}$ & 64.4 & 73.3 & 150.0 & 287.7 \\
\hline Stethojulis trilineata & $\mathrm{d}$ & BI & 197.1 & 123.3 & 105.0 & 425.4 \\
\hline Total no. of generalists & & & 20 & 20 & 11 & 51 \\
\hline Total generalist density (ind. $\mathrm{h}$ & & & 2059.1 & 1618.8 & 730.3 & 4408.2 \\
\hline Generalist density $(\%)$ & & & 46.7 & 36.7 & 16.6 & 100 \\
\hline \multicolumn{7}{|l|}{ Nursery species } \\
\hline Amblyglyphidodon curacao & $\mathrm{d}$ & $\mathrm{O}$ & 556.3 & 53.3 & & 609.6 \\
\hline Amphiprion ocellaris & $\mathrm{d}$ & $\mathrm{O}$ & 325 & 140 & & 465.0 \\
\hline Anyperodon leucogrammicus & $\mathrm{n}$ & $\mathrm{C}$ & 20 & 20 & & 40.0 \\
\hline Cephalopholis cyanostigma & $\mathrm{n}$ & $\mathrm{C}$ & 28.1 & 20 & & 48.1 \\
\hline Cheiloprion labiatus & $\mathrm{d}$ & $\mathrm{O}$ & 235 & 60 & 40 & 335.0 \\
\hline Labroides dimidiatus & $\mathrm{d}$ & BI & 102.8 & 40 & & 142.8 \\
\hline Lutjanus carponotatus & $\mathrm{n}$ & $\mathrm{C}$ & 40 & 20 & 20 & 80.0 \\
\hline L. fulviflamma & $\mathrm{n}$ & $\mathrm{C}$ & 30 & & 37.5 & 67.5 \\
\hline Myripristis murdjan & $\mathrm{n}$ & $\mathrm{O}$ & 70 & 20 & & 90.0 \\
\hline Neopomacentrus azysron & $\mathrm{d}$ & $\mathrm{O}$ & 783.3 & 100 & & 883.3 \\
\hline Parupeneus barberinus & $\mathrm{n}$ & BI & 20 & 26.7 & 20 & 66.7 \\
\hline Pomacentrus bankanensis & $\mathrm{d}$ & $\mathrm{O}$ & 225 & 46.7 & & 271.7 \\
\hline P. burroughi & $\mathrm{d}$ & $\mathrm{O}$ & 1145.8 & 40 & 20 & 1205.8 \\
\hline Scolopsis ciliatus & $\mathrm{d}$ & $\mathrm{C}$ & 40 & & 20 & 60.0 \\
\hline Total no. of nursery species & & & 14 & 12 & 6 & 32 \\
\hline Total nursery species density & $h a^{-1}$ ) & & 4541.3 & 2202.2 & 864.4 & 7607.9 \\
\hline Nursery species density (\%) & & & 59.7 & 28.9 & 11.4 & 100 \\
\hline
\end{tabular}


Table 3 (continued)

\begin{tabular}{|c|c|c|c|c|c|c|}
\hline \multirow{2}{*}{ Species } & \multirow{2}{*}{ Feeding activity } & \multirow{2}{*}{ Feeding guild } & \multicolumn{4}{|c|}{ Density (ind. ha ${ }^{-1}$ ) } \\
\hline & & & Coral & Transition & Seagrass & Total \\
\hline \multicolumn{7}{|l|}{ Seagrass residents } \\
\hline Abudefduf septemfasciatus & $\mathrm{d}$ & $\mathrm{O}$ & & 20.0 & 60.0 & 80.0 \\
\hline Acreichthys tomentosus & d & BI & & 80.0 & 25.0 & 105.0 \\
\hline Amblyglyphidodon batunai & $\mathrm{d}$ & $\mathrm{O}$ & 62.5 & 476.0 & 120.0 & 658.5 \\
\hline Amblygobius sp. & $\mathrm{d}$ & $\mathrm{D}$ & & 116.7 & 143.7 & 260.4 \\
\hline A. phalaena & d & $\mathrm{D}$ & & 225.0 & 235.0 & 460.0 \\
\hline Cheorodon anchorago & d & BI & 36.0 & 220.0 & 71.4 & 327.4 \\
\hline Chrysiptera brownrigii & d & $\mathrm{O}$ & & 57.8 & 50.0 & 107.8 \\
\hline C. cyanea & $\mathrm{d}$ & $\mathrm{O}$ & & 60.0 & 80.0 & 140.0 \\
\hline C. unimaculata & $\mathrm{d}$ & $\mathrm{O}$ & & 127.5 & 95.6 & 223.1 \\
\hline Dischistodus fasciatus & $\mathrm{d}$ & $\mathrm{O}$ & & 370.0 & 186.7 & 556.7 \\
\hline Halichoeres margaritaceus & d & BI & 168.7 & 250.5 & 455.2 & 874.4 \\
\hline Lethrinus harak & d & $\mathrm{C}$ & & 20.0 & 50.0 & 70.0 \\
\hline Neoglyphidodon oxyodon & $\mathrm{d}$ & $\mathrm{O}$ & & 170.0 & & 170.0 \\
\hline Pentapodus trivittatus & $\mathrm{d}$ & $\mathrm{C}$ & 20.0 & 77.8 & 96.0 & 193.8 \\
\hline Scolopsis lineatus & $\mathrm{d}$ & $\mathrm{C}$ & 20.0 & 72.5 & 153.3 & 245.8 \\
\hline Siganus canaliculatus & $\mathrm{d}$ & $\mathrm{H}$ & & 20.0 & 978.3 & 998.3 \\
\hline Upeneus tragula & $\mathrm{n}$ & BI & 25.0 & 40.0 & 125.8 & 190.8 \\
\hline \multicolumn{3}{|c|}{ Total no. of seagrass residents } & 6 & 17 & 16 & 39 \\
\hline \multicolumn{3}{|c|}{ Total seagrass resident density (ind. ha ${ }^{-1}$ ) } & 332.2 & 2303.8 & 2841 & 5477.0 \\
\hline \multicolumn{3}{|l|}{ Seagrass resident density $(\%)$} & 6.1 & 42.1 & 51.9 & 100 \\
\hline \multicolumn{3}{|l|}{ All species } & No. species & \multicolumn{2}{|c|}{ No. species $(\%)$} & Density (\%) \\
\hline \multicolumn{3}{|l|}{ Coral residents } & 15 & & & 43.3 \\
\hline \multicolumn{3}{|l|}{ Generalists } & 20 & & & 18.5 \\
\hline \multicolumn{3}{|l|}{ Nursery species } & 14 & & & 17.0 \\
\hline \multicolumn{3}{|l|}{ Seagrass residents } & 17 & & & 21.2 \\
\hline
\end{tabular}

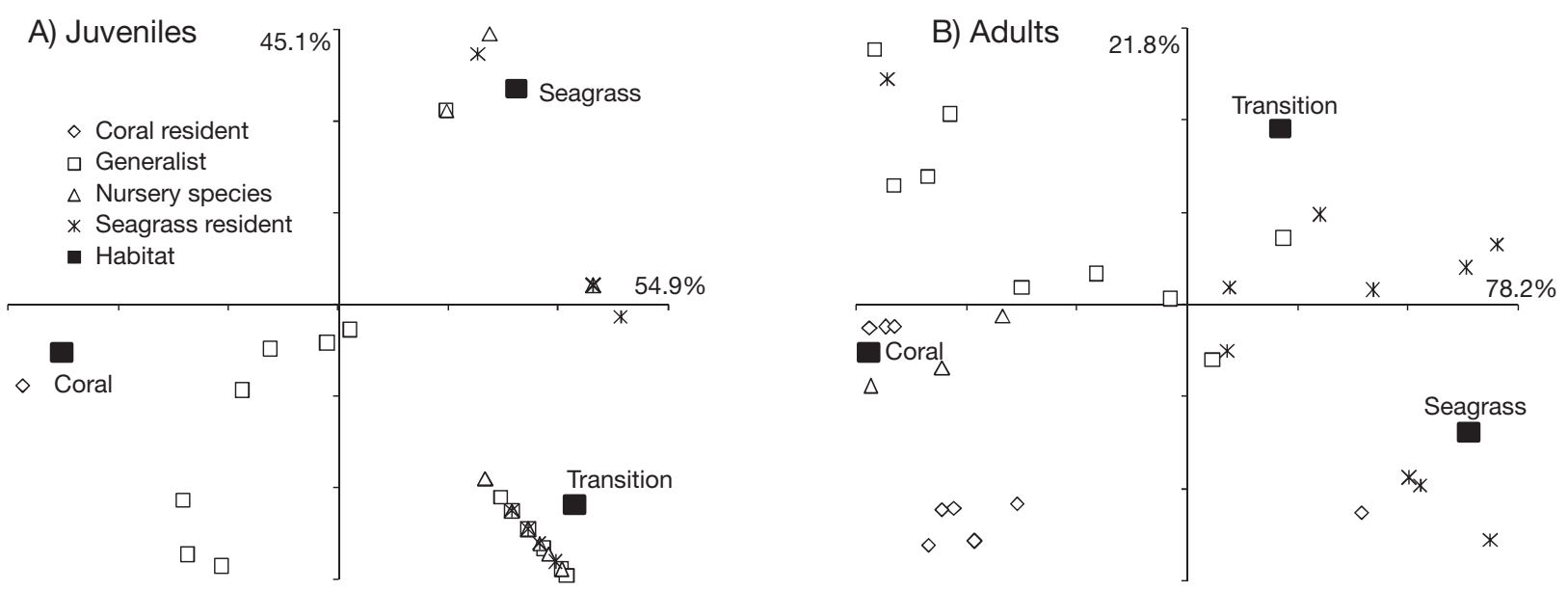

Fig. 3. Principal component analysis of mean densities of (A) juveniles and (B) adults of the observed species within the 3 habitats of coral, transition and seagrass

coral than in other habitats (Fig. 5). For generalists, the significant effects of habitat $\left(F_{2,42}=13.81, \mathrm{p}<0.001\right)$ and life history $\left(F_{1,42}=5.74, \mathrm{p}=0.021\right)$ on fish densities was explained by higher densities of adult and juvenile generalists in coral and transition habitats than in seagrass, while densities of adults were also higher than juveniles in all habitats (Fig. 5). For nursery species, the significant interaction between habitat and life history $\left(F_{2,42}=52.21, \mathrm{p}<0.001\right)$ revealed higher densities of adults in coral compared with transition and seagrass habitats, while juvenile densities were higher than adults in transition habitat, but not in seagrass (Fig. 5). An interaction between habitat and life history was also evident for seagrass residents $\left(F_{2,42}=11.60\right.$, $\mathrm{p}<0.001)$, and this pattern was generally opposite to that of the generalists (Fig. 5). For seagrass residents, higher densities of both adults and juveniles were found in seagrass and transition habitats than in coral 
habitats, while adult densities were higher than juvenile densities in transition and coral habitats. Overall, the results show a gradual transition in densities of

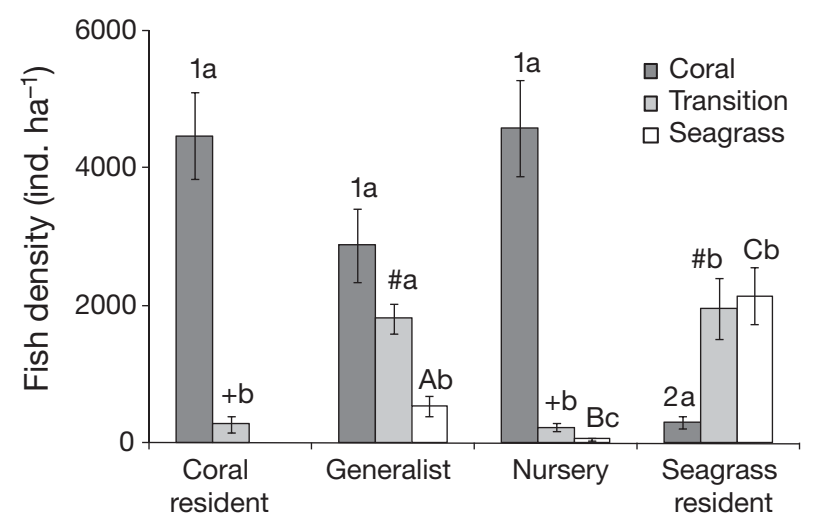

Fig. 4. Densities (adults and juveniles pooled; mean $\pm \mathrm{SE}$ ) of coral residents, generalists, nursery species and seagrass residents in 3 habitats (coral, transition, seagrass) within Karimunjawa National Park. Comparisons of mean fish densities among ecological groups and habitats were made using 2 -way analysis of covariance. Significant $(p<0.05)$ Tukey pairwise differences between ecological groups of fish in each habitat are represented by numbers, symbols and capital letters. For each ecological group, differences between habitats are represented by lowercase letters

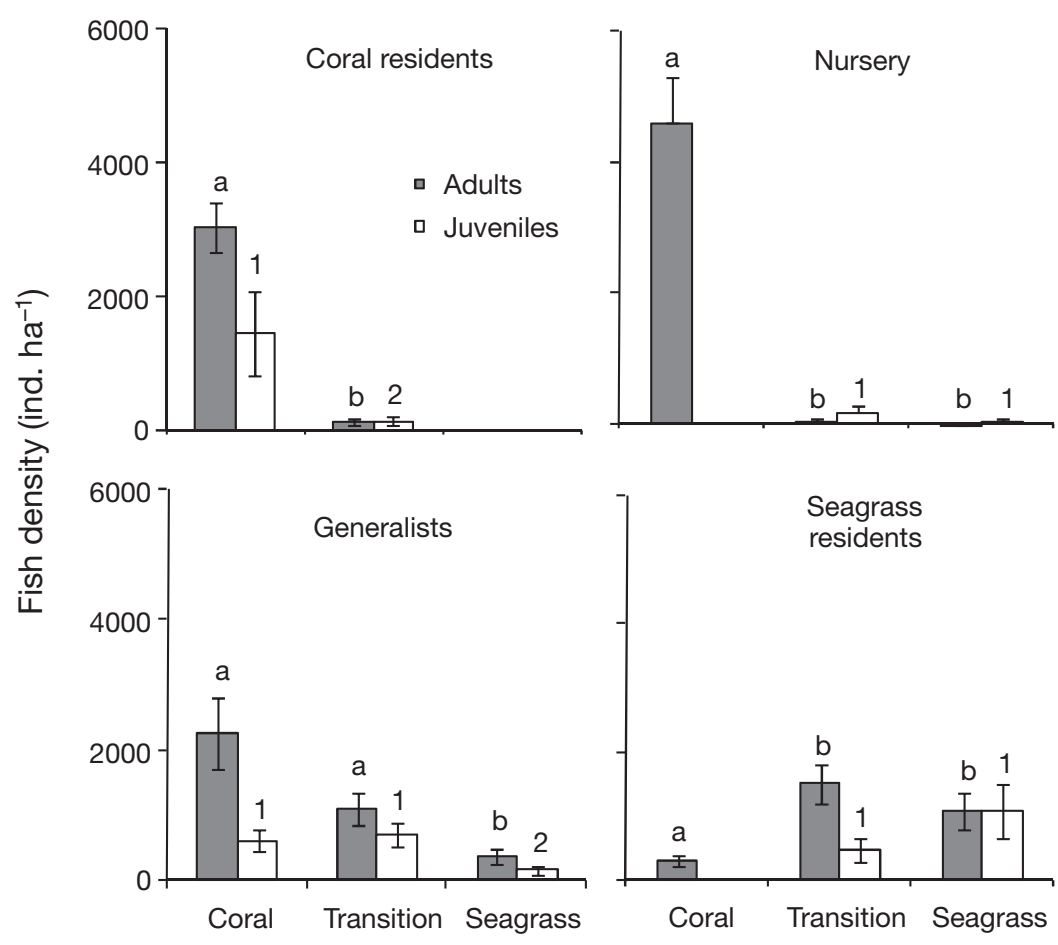

Fig. 5. Densities of adult and juvenile fish (mean $\pm 1 \mathrm{SE}$ ) of coral residents, generalists, nursery species and seagrass residents in 3 habitats (coral, transition, seagrass) in Karimunjawa National Park. Comparisons of mean fish densities between life history phases and among habitats were made using 2-way ANOVA. Significant $(p<0.05)$ Tukey pairwise differences between juvenile (adult) fish densities in each habitat are represented by letters (numbers) ecological groups from coral to seagrass sites, which is consistent with intermediate fish species richness and densities found in transition habitats (Fig. 2).

For diurnal species, a positive interaction between habitat and feeding type $\left(F_{2,101}=3.86, \mathrm{p}=0.012\right)$ was explained by higher densities of omnivores than the 3 other feeding groups in corals (Fig. 6). Higher densities of zoobenthivores were also found in corals compared with transition habitat. No differences in the mean density of piscivores or herbivores were found among habitats (Fig. 6a), but overall, higher densities of diurnal piscivores and herbivores were recorded in seagrass compared with corals. For nocturnal species, no effect of habitat $\left(F_{2,15}=0.25, \mathrm{p}=0.782\right)$ or feeding type $\left(F_{2,15}=0.13, \mathrm{p}=0.721\right)$ was found, although generally, the highest mean densities of zoobenthivores were found in seagrass habitat, and the highest mean densities of piscivores were found in coral and transition habitat (Fig. 6b).

\section{DISCUSSION}

We hypothesised that the configuration of seagrass-coral reef habitats would have a clear influence on the fish assemblages that used these habitats. Our observations are consistent with this hypothesis. Firstly, coral habitats were characterised by high numbers of species, high fish densities and high adult densities. Secondly, in contrast to this, open seagrass and transition habitats were characterised by lower numbers of species and low adult densities. Compared to coral reef habitats, both seagrass and transition habitats have a lower structural complexity but are easily accessible from the coral reef. In addition, the total number of fish species (212) observed in Karimunjawa represents an almost 2-fold greater diversity than a comparable study in Indonesia (Unsworth et al. 2008), is up to 4-fold greater than studies in the Caribbean (Nagelkerken \& van de Velde 2004) and East Africa (Dorenbosch et al. 2005, 2007), and is comparable to studies in Japan (Nakamura \& Sano 2004a). Our findings, including patterns in habitat utilisation by fish, are therefore possibly more likely to have relevance in the IndoPacific where the diversity of fish species is comparable to Karimunjawa (see Allen \& Werner 2002). 


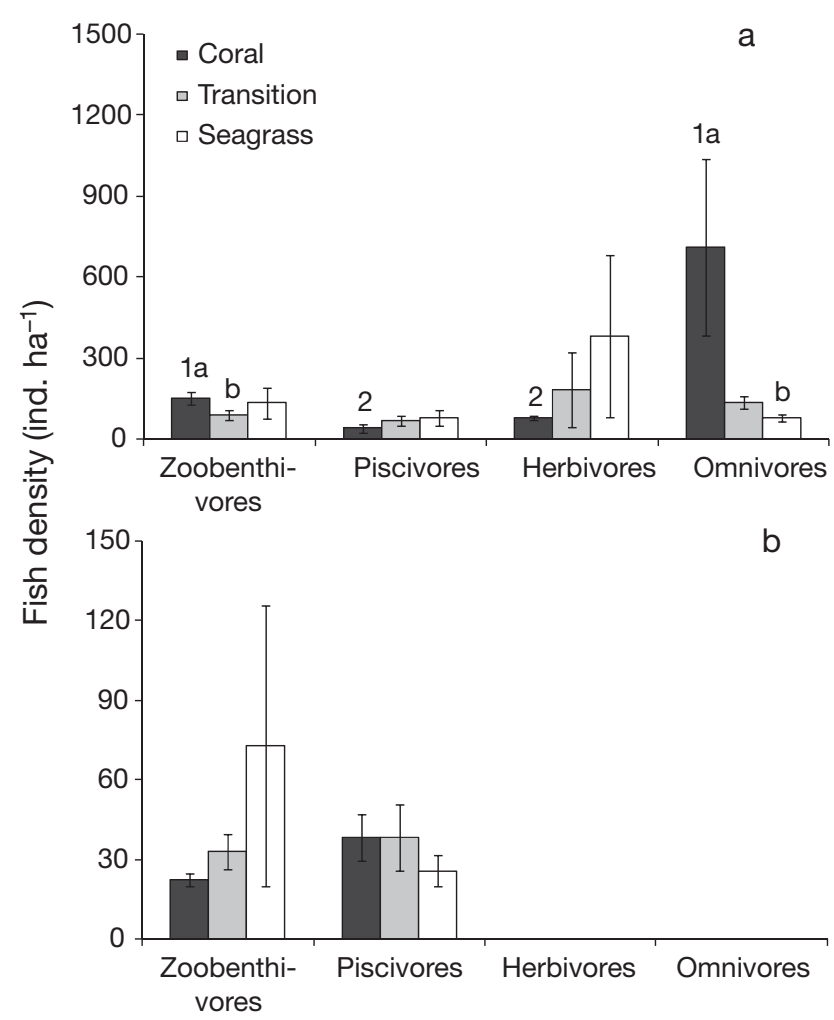

Fig. 6. Densities (mean $\pm 1 \mathrm{SE}$ ) of (a) diurnal and (b) nocturnal zoobenthivores, piscivores, herbivores and omnivores in 3 habitats (coral, transition, seagrass) in Karimunjawa National Park. Comparisons of mean fish densities among feeding groups and habitats were made using 2-way ANOVA. Significant $(p<0.05)$ Tukey pairwise differences between feeding groups in each habitat are represented by numbers. For each feeding group, differences between habitats are represented by lowercase letters

An important finding of our study was that distinct assemblages of ecological and feeding groups were present within all 3 habitats, irrespective of location. This suggests that many species have specific preferences for habitats within seagrass-coral reef gradients, with the distribution of the 4 ecological groups changing with habitat and many common species of fish shared between seagrass and transition habitats and between transition and coral habitats. The partitioning of reef fish density into coral residents (43.3\%), generalists $(18.5 \%)$, nursery species $(16.9 \%)$ and seagrass residents $(21.2 \%)$ was comparable to the findings of Dorenbosch et al. (2005), who examined similar fish characteristics in East Africa. In Karimunjawa, generalists and coral residents had the most even distribution of juvenile and adult species among habitats, which suggests that these species possibly use seagrass habitat as a source of additional food resources. In contrast, adult and juvenile seagrass residents showed highest densities in seagrass and transition habitats, which implies an important nursery function of seagrass for some coral reef species as reported elsewhere in the Indo-Pacific (Dorenbosch et al. 2005, Lugendo et al. 2006, Unsworth et al. 2009a,b). Distance from shore also influenced seagrass resident density, implying that distance and its likely constraints on movement may be important in regulating fish densities in seagrass beds.

Transition and seagrass habitats were important for juvenile nursery species and seagrass residents, while 13 species observed on coral reefs may use seagrass for nursery functions. These included juveniles with important functional roles such as the predatory omnivores Lutjanus caropnotatus and L. fulviflamma (snappers) and the piscivores Anyperodon leucogrammicus and Cephalopholis cyanostigma (groupers), that may not directly influence high coral reef fish diversity but are likely to be important in structuring reef communities (Mumby et al. 2007). Nursery species also included the commercially important aquarium damselfish Amphiprion ocellaris. The densities of adult nursery species Amblyglyphidodon curacao, Neopomacentrus azysron and Pomacentrus burroughi in coral habitats were higher than densities of adult nursery species in seagrass and transition habitats, but the association of juvenile fish with transition and seagrass habitats suggests that these habitats provide a nursery role for these juveniles. Further, the lack of relationship of nursery species density with distance from shore suggests that habitat and not distance from shore may be the key feature constraining movements and shaping nursery species assemblages in these habitats.

Similar observations of the dependence of functionally important species on habitat have been made in Indonesia (Unsworth et al. 2009a,b), and their distribution is likely to be explained by a combination of ecological processes, such as short-distance migration, ontogenetic migration, predation, feeding and seeking shelter within habitats (Dorenbosch et al. 2005, 2006). Adult reef-associated species (i.e. non-nursery species) may migrate short distances away from the reef towards adjacent habitats for food (Tulevech \& Recksiek 1994, Kaunda-Arara \& Rose 2004) and increase densities of some non-nursery species in habitats adjacent to the reef. Seagrass beds within the Indo-Pacific may also function as corridors between mangroves and coral reefs for fish that undertake ontogenetic migrations, from shallow water habitats to the reef, once they mature (Lugendo et al. 2005).

Attributes of seagrass structure, including seagrass canopy height, seagrass cover and shoot density can be important determinants of fish assemblage structure and in particular juvenile fish densities (Gullström et al. 2008). However, we found no evidence to suggest that the high densities of seagrass residents and juvenile nursery species in seagrass habitat were influ- 
enced by seagrass structural characteristics. Because seagrass beds in Karimunjawa are dominated by Enhalus acoroides, Thalassia hemprichii and Cymodocea spp., which for the most part have relatively high canopies, irrespective of shoot cover and density, we conclude that on the level of a single site, juvenile or adult fish densities appear to bear no relationship with seagrass species composition. Other studies have also found that the presence or absence of seagrass is a more important determinant of fish density and structure than seagrass species composition (Jenkins \& Wheatley 1998, Nakamura \& Sano 2004b, Webster 2004, Dorenbosch et al. 2005). Further, as seagrass residents were highly associated with areas close to shore, irrespective of habitat, other factors associated with distance from shore, including ecological and feeding processes, and food and shelter resource availability (Dorenbosch et al. 2005, 2006), may be constraining their movement away from the shore.

Although we did not attempt to examine the effects of habitats on fish assemblage structure in detail, we examined feeding ecology as it is likely to influence differences in fish densities and may to some extent explain the structure of fish assemblages in different habitats (Dorenbosch et. al 2005, Unsworth et al. 2009a). Of the diurnal feeders, zoobenthivores and omnivores were predominantly found in coral and transition habitats. Both feeding groups comprised 11 of the 15 species of coral residents, with $81 \%$ of their total density found in coral and transition habitats. This is consistent with the feeding preferences of zoobenthivores (Coris batuensis, Halichoeres melanochir, H. marginatus) and omnivores (Chromis artipectoralis, Dascyllus reticulatus) on benthic and planktonic invertebrates on shallow coral reefs (Froese \& Pauly 2006) and the feeding preference of pomacentrid and acanthurid diurnal omnivores for scleractinian coral habitats (Bouchon Navaro 1986, Allen et al. 2003).

The preference for coral habitats by diurnal zoobenthivores and omnivores could be a strategy that optimises their daytime survival through avoidance of predatory diurnal piscivores, which largely inhabit the relatively open transition and seagrass habitats. In contrast, high densities of nocturnal zoobenthivore species were found in seagrass beds and transition areas, in particular Upeneus tragula, which has a preference for prey from these habitats (Froese \& Pauly 2006). This pattern contrasts with Dorenbosch et al. (2005), who found almost $70 \%$ of nocturnal zoobenthivores in coral and transition habitats. For some species of diurnal zoobenthivores (Acreichthys tomentosus, Halichoeres margaritaceous, U. tragula and Cheorodon anchorago), the strong preference for seagrass is also consistent with their distribution and feeding behaviour within shallow corals (Allen et al. 2003).
Herbivores showed a clear preference for transition and seagrass sites. Of the 3 species in this group, Chlororus sordudus and Scarus ghobban, from the families Labridae and Scaridae respectively, were generalists while Siganus canalicultus was a seagrass resident. Daytime habitat segregation within the herbivore group may reduce competition among species and thereby increase optimal foraging (Dorenbosch et al. 2005). Similarly, the separation of habitat preference between nocturnal and diurnal species within other feeding groups may also reflect optimisation of foraging strategies that helps to reduce competition for resources among species.

The segregation between diurnal and nocturnal piscivores generally showed an opposite pattern to that of zoobenthivores, with the highest densities of nocturnal species found in non-seagrass habitats. Nocturnal piscivores were most represented by Lethrinidae and Lutjanidae spread among the 4 ecological groups, and included coral residents (Cephalopholis microprion), generalists (Epinephelus merra, Lutjanus decussatus) and nursery species (L. carponotatus, C. cyanostigma, Anyperodon leucogrammicus) that target prey found in coral habitats (Froese \& Pauly 2006). As these nocturnal species are inactive during daytime, and juveniles require protection from predators, it is possible, for some species found in high densities in seagrass (e.g. L. fulviflamma), that the structurally complex, high canopied seagrasses (e.g. Enhalus acoroides, Cymodocea serrulata and Thalassia hemprichii) afford protection from predation, as reported elsewhere (Cocheret de la Morinière et al. 2002, Nakamura \& Sano 2004a, Verweij et al. 2006). The high densities of diurnal piscivores, such as the seagrass residents Lethrinus harak and Pentapodus trivittatus, the nursery species Scolopsis lineatus and the generalist L. erythropterus, also suggests that juveniles of these species utilise seagrass habitats for feeding, as reported for juveniles of L. harak in Indonesia (Unsworth et al. 2009b).

The findings compare favourably with the few studies in South East Asia that have defined the important functional role of seagrass beds as juvenile fish habitat for various reef-associated fish species (Unsworth et al. 2009a,b). In the present study, habitat segregation among numbers of fish species, overall fish densities, life stages and functional groups of coral reef fishes were found along seagrass-coral gradients. Predictably, densities of coral reef residents and generalist species were highest in coral habitats, but high densities of seagrass residents and nursery species, including 14 juvenile reef species, highlights the important role that seagrasses may play in ecosystem connectivity and function. Preferences for seagrass and transition habitats by nocturnal zoobenthivores and diurnal 
piscivores, and contrasting habitat preferences for diurnal omnivores, diurnal zoobenthivores and nocturnal piscivores, implies that 'habitat segregation' may optimise foraging and survival through reduced competition for resources and avoidance of predation. Our findings in KNP support the hypothesis that, through processes of habitat connectivity (e.g. nursery function and foraging areas), seagrass beds appear to be important for fisheries production and should be an integral part of marine protected areas that aim to support the productivity, biodiversity and resilience of coral reefs.

Acknowledgements. The authors are grateful to the financial contribution of the David and Lucile Packard Foundation, the logistical support provided by staff of the Balai Taman Nasional based in Semarang and Karimunjawa, the agency responsible for marine park management in Karimunjawa. The collection of fisheries data would not have been possible without the kind co-operation of local fishing communities in Karimunjawa. S. Pardede made significant contribution to the design, co-ordination and implementation of the study, R. K. Unworth provided useful comments to the manuscript and A. S. Hoey assisted with statistical analyses.

\section{LITERATURE CITED}

Allen G, Werner TB (2002) Coral reef fish assessment in the 'coral triangle' of southeastern Asia. Environ Biol Fishes 65:209-214

Allen G, Steene R, Humann P, Deloach N (2003) Reef fish identification: Tropical Pacific. New World Publications, Jacksonville, FL

> Ashworth JS, Ormond RFG, Sturrock HT (2004) Effects of reef-top gathering and fishing on invertebrate abundance across take and no-take zones. J Exp Mar Biol Ecol 303: 221-242

Bouchon-Navaro Y (1986) Partitioning of food and space resources by chaetodontid fishes on coral reefs. J Exp Mar Biol Ecol 103:21-40

Campbell SJ, McKenzie LJ (2004) Flood related loss and recovery of intertidal seagrass meadows in southern Queensland, Australia. Estuar Coast Shelf Sci 60:477-490

Campbell SJ, Pardede ST (2006) Reef fish structure and cascading effects in response to artisanal fishing pressure. Fish Res 79:75-83

Cocheret de la Morinière E, Pollux BJA, Nagelkerken I, van der Velde G (2002) Post-settlement life cycle migration patterns and habitat preference of coral reef fish that use seagrass and mangrove habitats as nurseries. Estuar Coast Shelf Sci 55:309-321

de la Torre-Castro M, Rönnbäck P (2004) Links between humans and seagrasses - an example from tropical East Africa. Ocean Coast Manag 47:361-387

Dorenbosch M, van Riel MC, Nagelkerken I, van der Velde G (2004) The relationship of reef fish densities of mangrove and seagrass nurseries. Estuar Coast Shelf Sci 60:37-48

> Dorenbosch M, Grol MGG, Nagelkerken I, van der Velde G (2005) Distribution of coral reef fishes along a coral reef-seagrass gradient: edge effects and habitat segregation. Mar Ecol Prog Ser 299:277-288

> Dorenbosch M, Grol MGG, Nagelkerken I, van der Velde G (2006) Different surrounding landscapes may result in different fish assemblages in east African seagrass beds. Hydrobiologia 563:45-60

Dorenbosch M, Verbek W, Nagelkerken I, van de Velde G (2007) Influence of habitat configuration on connectivity between fish assemblages of Caribbean seagrass beds, mangroves and coral reefs. Mar Ecol Prog Ser 334: 103-116

> Eklöf JS, Frocklin S, Lindvall A, Stadlinger N, Kimathi A, Uku JN, McClanahan TR (2009) How effective are MPAs? Predation control and 'spill-in effects' in seagrass coral reef lagoons under contrasting fishery management. Mar Ecol Prog Ser 384:83-96

English S, Wilkinson C, Baker V (1997) Survey manual for tropical marine resources. Australian Institute of Marine Science, Townsville

Froese R, Pauly DE (2006) FishBase. Available at www. fishbase.org (accessed 15 April 2006)

Gell FR, Whittington MW (2002) Diversity of fishes in the Quirimba Archipelago, northern Mozambique. Mar Freshw Res 53:115-121

> Gullström M, Bodin M, Nilsson PG, Öhman MC (2008) Seagrass structural complexity and landscape configuration as determinants of tropical fish assemblage composition. Mar Ecol Prog Ser 363:241-255

Heck KL, Valentine JF (2007) The primacy of top-down effects in shallow benthic ecosystems. Estuaries Coasts 30: 371-381

> Horinouchi M, Nakamura Y, Sano M (2005) Comparative analysis of visual censuses using different width striptransects for a fish assemblage in a seagrass bed. Estuar Coast Shelf Sci 65:53-60

Jenkins GPH, Wheatley MJ (1998) The influence of habitat structure on nearshore fish assemblages in a southern Australian embayment: comparison of shallow seagrass, reef algal, and unvegetated sand habitats, with emphasis on their importance for recruitment. J Exp Mar Biol Ecol 218:1031-1125

Jenkins GPH, May MA, Wheatley MJ, Holloway MG (1997) Comparison of fish assemblages associated with seagrass and adjacent unvegetated habitats of Port Phillip Bay and Corner Inlet, Victoria, Australia, with emphasis on commercial species. Estuar Coast Shelf Sci 44:569-588

Kaunda-Arara B, Rose GA (2004) Out-migration of tagged fishes from marine reef national parks to fisheries in coastal Kenya. Environ Biol Fishes 70:363-372

Kirkman H, Kirkman JA (2002) The management of seagrasses in Southeast Asia. Bull Mar Sci 71:1379-1390

Lugendo BR, Pronker A, Cornelissen I, de Groene A and others (2005) Habitat utilisation by juveniles of commercially important fish species in a marine embayment in Zanzibar, Tanzania. Aquat Living Resour 18:149-158

Lugendo BR, Nagelkerken I, van der Velde G (2006) The importance of mangroves, mud and sand flats, and seagrass beds as feeding areas for juvenile fishes in Chwaka Bay, Zanzibar: gut content and stable isotope analyses. J Fish Biol 69:1639-1661

Moksnes PO, Gullström M, Tryman K, Baden S (2008) Trophic cascades in a temperate seagrass community. Oikos 117: 763-777

> Mumby PJ (2006) Connectivity of reef fish between mangroves and coral reefs: algorithms for the design of marine reserves at seascape scales. Biol Conserv 128:215-222

Mumby PJ, Edwards AJ, Ernesto Arias-González J, Lindeman $\mathrm{KC}$ and others (2004) Mangroves enhance the biomass of coral reef fish communities in the Caribbean. Nature 427: 533-536

> Mumby PJ, Dahlgren C, Harborne A, Kappel C and others (2006) Fishing, trophic cascades, and the process of graz- 
ing on coral reefs. Science 311:98-101

Mumby PJ, Hastings A, Edwards HJ (2007) Thresholds and the resilience of Caribbean coral reefs. Nature 450: 98-101

Nagelkerken I (2009) Evaluation of nursery function of mangroves and seagrass beds for tropical decapods and reef fishes: patterns and underlying mechanisms. In: Nagelkerken I (ed) Ecological connectivity among tropical coastal ecosystems. Springer, New York, NY, p 357-400

Nagelkerken I, van der Velde G (2004) A comparison of fish communities of subtidal seagrass beds and sandy seabeds in 13 marine embayments of a Caribbean island, based on species, families, size distribution and functional groups. J Sea Res 52:127-147

Nagelkerken I, Dorenbosch M, Verberk WCEP (2000a) Importance of shallow water biotypes of a Caribbean bay for juvenile coral reef fishes: a pattern of biotype association, community structure and spatial distribution. Mar Ecol Prog Ser 202:175-192

Nagelkerken I, van der Velde G, Gorissen MW, Meijer GJ, van't Hof T, den Hartog C (2000b) Importance of mangroves, seagrass beds and the shallow coral reef as a nursery for important coral reef fishes, using a visual census technique. Estuar Coast Shelf Sci 51:31-44

> Nagelkerken I, Kleijnen S, Klop T, van den Brand RACJ, Cocheret de la Morinière E, van der Velde G (2001) Dependence of Caribbean reef fishes on mangroves and seagrass beds as nursery habitats: a comparison of fish faunas between bays with and without mangroves/seagrass beds. Mar Ecol Prog Ser 214:225-235

Nagelkerken I, Roberts CM, van der Velde G, Dorenbosch M, van Riel MC, Cocheret de la Morinière E, Nienhuis $\mathrm{PH}$ (2002) How important are mangroves and seagrass beds for coral reef fish? The nursery hypothesis tested on an island scale. Mar Ecol Prog Ser 244:299-305

Nakamura Y, Sano M (2004a) Overlaps in habitat use of fishes between a seagrass bed and adjacent coral and sand areas at Amitori Bay, Iriomote Island, Japan: importance of the seagrass bed as juvenile habitat. Fish Sci 70:788-803

Nakamura Y, Sano M (2004b) Is there really lower predation risk for juvenile fishes in a seagrass bed compared with an adjacent coral area? Bull Mar Sci 74:477-482

Nemeth RS (2009) Dynamics of reef fish and decapod crustacean spawning aggregations: underlying mechanisms, habitat linkages and trophic linkages. In: Nagelkerken I (ed) Ecological connectivity among tropical coastal ecosystems. Springer, New York, NY, p 73-134

Ries L, Sisk T (2004) A predictive model of edge effects. Ecology 85:2917-2926

Editorial responsibility: Matthias Seaman, Oldendorf/Luhe, Germany
Sale PF, Cowen RK, Danilowicz BS, Jones GP and others (2005) Critical science gaps impede use of no-take fishery reserves. Trends Ecol Evol 20:74-79

> Sheaves M (2005) Nature and consequences of biological connectivity in mangrove systems. Mar Ecol Prog Ser 302: 293-305

Spalding M, Taylor M, Ravilious C, Short F, Green E (2003) Global overview: the distribution and status of seagrasses. In: Green EP, Short FT (eds) World atlas of seagrasses. UNEP World Conservation Monitoring Centre, University of California Press, Berkeley, CA, p 5-25

Stoner AW (2003) What constitutes essential nursery habitat for a marine species? A case study of habitat form and function for queen conch. Mar Ecol Prog Ser 257:275-289

Tulevech SM, Recksiek CW (1994) Acoustic tracking of adult white grunt, Haemulon plumieri, in Puerto Rico and Florida. Fish Res 19:301-319

> Unsworth KF, Cullen LC (2010) Recognising the necessity for Indo-Pacific seagrass conservation. Conserv Lett 3:63-73

> Unsworth RKF, Bell JJ, Smith DJ (2007a) Tidal fish connectivity of reef and seagrass habitats in the Indo-Pacific. J Mar Biol Assoc UK 87:1287-1296

> Unsworth RKF, Wylie E, Smith DJ, Bell JJ (2007b) Diel trophic structuring of seagrass bed fish assemblages in the Wakatobi Marine National Park, Indonesia. Estuar Coast Shelf Sci 72:81-88

> Unsworth RKF, De Leon PS, Garrard S, Jompa J, Smith DJ, Bell JJ (2008) High connectivity of Indo-Pacific seagrass fish assemblages with mangrove and coral reef habitats. Mar Ecol Prog Ser 353:213-224

Unsworth RKF, Garrard SL, De León PS, Cullen LC, Smith DJ, Sloman KA, Bell JJ (2009a) Structuring of Indo-Pacific fish assemblages along the mangrove-seagrass continuum. Aquat Biol 5:85-95

Unsworth RKF, De León PS, Garrard SL, Smith DJ, Wylie E, Smith DJ, Bell JJ (2009b) Habitat usage of the thumbprint emperor Lethrinus harak (Foskaåal, 1775) in an IndoPacific coastal seascape. Open Mar Biol J 3:16-20

- Verweij MC, Nagelkerken I, de Graaff D, Peeters M, Bakker EJ, van de Velde G (2006) Structure, food and shade attract juvenile coral reef fish to mangrove and seagrass habitats: a field experiment. Mar Ecol Prog Ser 306: $257-268$

Waycott M, Duarte CM, Carruthers TJB, Orth RJ and others (2009) Accelerating loss of seagrasses across the globe threatens coastal ecosystems. Proc Natl Acad Sci USA 106:12377-12381

Webster MS (2004) Density dependence via intercohort competition in coral-reef fish. Ecology 85:986-994

Submitted: June 13, 2007; Accepted: May 2, 2011

Proofs received from author(s): June 28, 2011 